DOI: 10.21779/2077-8155-2019-10-3-20-30

УДК 215:297.1

М.И. Билалов ${ }^{I}$
Содержание статьи

Введение
Философия ислама и ислам
Философия ислама и разум
Исламская философия и арабо-
мусульманская философия
Претензии исламской философии
на то, что только ей доступно
истинное познание
Исламская философия и
национальная
Дагестана философия
Выводы

\section{Информация о статье}

Поступила в редакцию: 05.07.2019.

Передана на рецензию: 11.07.2019.

Получена рецензия: 08.08.2019.

Принята в номер: 30.08.2019.

\title{
Философия ислама о специфике исламской философии
}

\section{Дагестанский государственный университет; mibil@ mail.ru}

В статье выявляются особенности исламской философии в контексте взаимоотношений религии и философии, религии и науки. Ссылаясь на основоположников философии ислама, автор говорит о том, что, как считают исламские ученые, мусульманство является всеобъемлющей самодостаточной мировоззренческой системой, совмещая в себе науку, философию и религию. Показано отношение к специфике исламской философии полемики о «логико-смысловой теории» А.В. Смирнова. Автор излагает свои взгляды на ислам и его философию и приходит к выводу, что необходимо выработать новый тип мышления для совершения «революции», «великого джихада», который столетиями является предметом острых политических и теоретических дискуссий мусульманской уммы.

В статье автор излагает свои идеи о влиянии мусульманской философии на общественно-политическую мысль народов мусульманских регионов России, в частности Дагестана. Предполагается, что дальнейшее развитие дагестанской философии будет происходить не только путем освоения мировой философии в ее классических и неклассических проявлениях, но и приобщением к мыслительной стратегии исламской философии. По мнению автора, значительным подспорьем может стать университетское философское и зарождающееся теологическое образование в вузах Дагестана. Необходимо сотрудничество светского философского образования с исламским теологическим образованием.

Ключевые слова: философия ислама, исламская философия, разум, раџиональность, иррациональность, суфизм.

DOI: 10.21779/2077-8155-2019-10-3-20-30

UDC 215:297.1

Content of the article

Information about the article

\footnotetext{
${ }^{1}$ Мустафа Исаевич Билалов - заведующий кафедрой онтологии и теории познания ДГУ. доктор философских наук, профессор.
} 
Bilalov M.I. The philosophy of Islam on the specifics of Islamic philosophy // Islamovedenie. 2019. V. 10, № 3. P. 20-30

$\begin{array}{lll}\text { M.I. Bilalov } & \text { Introduction. } & \text { Received: 05.07.2019. } \\ & \text { Philosophy of Islam and Islam. } & \text { Submitted for review: 11.07.2019. } \\ & \text { Philosophy of Islam and reason. } & \text { Review received: 08.08.2019. } \\ & \text { Islamic philosophy and Arab-Muslim } & \text { Accepted for publication: 30.08.2019. } \\ \text { philosophy. } & \\ & \text { Islamic philosophy claims to be the } \\ & \text { only source of knowledge } \\ & \text { Islamic philosophy and national } \\ & \text { philosophy of Dagestan. } \\ & \text { Summary. } \\ & \text { Conclusion. }\end{array}$

\section{Philosophy of Islam on the Specifics of Islamic Philosophy}

\section{Dagestan State University; mibil@mail.ru}

The article reveals the peculiarities of Islamic philosophy in the context of interrelationships between religion and philosophy, religion and science. With reference to the founders of the philosophy of Islam, the author maintains that, according to Islamic scholars, Islam as a comprehensive self-sufficient worldview system combines science, philosophy and religion. The article shows the simplification of the information of Islamic philosophy to reason, the attitude to the specifics of Islamic philosophy of the controversy about the"logical-semantic theory" of A.V. Smirnov. The comprehension of Islam and its philosophy in the article implies the need to develop a new type of thinking for making the "revolution", "the great Jihad", which for centuries appears to be a subject of acute political and theoretical discussions by the Muslim Ummah.

The author's ideas about the influence of Muslim philosophy on the socio-political thought of the peoples of the Muslim regions of Russia, in particular Dagestan, are presented. The further development of Dagestan philosophy will go both in the line of mastering the world philosophy in its classical and non-classical manifestations, and introducing the thinking strategy of Islamic philosophy. According to the author, university philosophical education and nascent theological education at Dagestan universities appears here as a significant support. Cooperation between secular philosophical education and Islamic theological education is necessary.

Keywords: philosophy of Islam, Islamic philosophy, reason, rationality, irrationality, Sufism.

\section{Введение}

Философия ислама и исламская философия при всей кажущейся терминологической синонимичности разнятся по своему предмету. Правда, ни в интернете, ни в специальной литературе и справочниках не объясняется, чем они отличаются друг от друга. На самом деле исламская философия - это совокупность учений мусульманских философов. С этим понятием проблем нет, здесь все предельно ясно. Философия ислама также может толковаться как совокупность учений, но более точное ее определение - разновидность философии религии, некая методология исламской религии, в том числе и исламской философии. Речь идет о более широкой теоретической рефлексии в рамках современных философских размышлений, выходящих за пределы проблематики мусульманской философии. Достаточно назвать имена Ф. Роузенталя, Г. Грюнебаума, А. Меца, С. Насра, М. Икбала, наших современных соотечественников-исламоведов В. Бартольда, Е. Бертельса, Т.Ибрагима, А. Сагадеева, Г. Каримова, М. Степанянц, Р. Хайрутдинова, В. Наумкина, А. Смирнова, Е. Фроловой, северокавказских исследователей - Г. Баммата, А. Шихсаидова, М. Абдуллаева, А. Яндарова, Н. Османова, В. Акаева и других авторов, которые изучали разные аспекты исламской культуры, религии и философии. В их трудах и формируется философия

\footnotetext{
${ }^{2}$ Mustafa Isaevich Bilalov - Dr. Sc. (Philosophy), Professor, Head of the Department of Ontology
} and Theory of Knowledge, DSU. 
ислама. В данной статье мы учли все уточнения, касающиеся содержания терминов, и попытались выделить несколько особенностей исламской философии.

\section{Философия ислама и ислам}

В советской философии традиционно считалось, что между религией и философией как историческими типами мировоззрений никогда не было единства и тем более гармонии. Но это на первый, поверхностный взгляд. Разумеется, противоречия между ними есть, они реальны и обусловлены как внутренней природой этих мировоззрений, так и духовной ситуацией в обществе, о чем свидетельствуют факты из разных периодов истории. Но эти противоречия никогда не приводили к тому, чтобы они пытались заменить друг друга, точнее, чтобы более молодая форма общественного сознания - философия стремилась поглотить и сущностные качества, и функциональные свойства своей предшественницы.

В своей монографии «Философская и религиозная составляющие человеческого духа» М. Келигов обосновывает «утверждение идеи глубинного взаимопроникновения философии и религии, с одной стороны, и их неустранимого противоборства и противостояния - с другой» [10, с. 128]. Автор резонно не соглашается с Гегелем, считавшим, что философия не может существовать без религии и содержит ее внутри себя, тогда как религия может существовать без философии. Обстоятельно обосновывается мысль о том, что религия «после того как возникла философия, уже тоже не может обойтись без последней» [10, с. 130]. Не согласен ученый и с утверждением Спинозы, Ницше и других философов о том, что нет никакой связи между религией и философией. Вывод монографии - «нормальное состояние между философским и религиозным духом - это состязательность, интеллектуальное противоборство, но не война и не подавление и устранение друг друга» [10, с. 148]. Мы согласны с тем, что, «не отвергая принципиального различия между философией и религией в целях, средствах и критериях познания, а также признавая возможность доминирования каждой из них в определенную историческую эпоху, важно укрепить в сознании не только верующих, но и всех людей мысль о самоценности и взаимодополнительности этих духовно-мировоззренческих формообразований» [10, с. 128].

Что касается связи той или иной религии и ее философии как теоретической выжимки религии, то последняя, зарождаясь и развиваясь в лоне религиозного мировоззрения, пытается оправдать и обосновать его состоятельность. Наиболее продвинутые в интеллектуальном отношении представители исламской философии также занимаются теоретическим оправданием и обоснованием ислама. Эти связи, в отличие от рассмотренных выше взаимоотношений религии и философии как исторических форм мировоззрения, - связи генетические, причинно-следственные.

Считается, что в буддизме религия и философия нераздельны. В христианстве, наоборот, его философия начала формироваться раньше религии, обрела значительную самостоятельность и переросла со временем в независимое теоретическое мировоззрение, впитавшее во многом идеи античной философии и более поздних теоретических систем. Более того, порожденная христианством философия могла обосновывать идеи, противоречащие вероучению (вплоть до атеизма). Связи ислама и его философии несколько иные. Исламская философия возникла относительно поздно, спустя почти два века после самой религии, хотя в этой философии также синтезированы доисламские идеи тысячелетней давности древнегреческой философии. Но они были органически вписаны в мусульманское религиозное мировоззрение, которому его философия всегда была верна. В этом смысле ислам справедливо претендует на совмещение в себе науки, философии и религии, позиционируя себя как всеобъемлющую мировоззренческую систему, 
вполне самодостаточную для определения всей человеческой жизни в ее прошлом и будущем.

Один из родоначальников исламской философии аль-Кинди не противопоставлял вероисповедание и образование (науку): «Воистину нет веры у того, кто противится приобретению знаний об истинной природе вещей...» [2, с. 713]. Своим творчеством в области наук, философии и религии он демонстрировал их единство. Его младший соратник, также выдающийся основоположник мусульманской философии, ученый-энциклопедист аль-Фараби, следуя за Аристотелем, делил науки на теоретические и практические, отдавая предпочтение разуму как философии, которая неотделима от религии. По его мнению, вероучение и философия охватывают одни и те же предметы. Они «выдвигают конечные принципы, начала существующих вещей, они дают знание первоначала и первопричины существующих вещей...» [3, с. 338]. Традиция выведения философских знаний из научных (это и есть традиция аристотелевской метафизики) и приведение их в полное соответствие с положениями Корана сохранялась все время существования исламской религии.

При этом мусульманская философия, как и сама мусульманская религия, прошла весьма сложный путь своего становления и развития через догматизацию, свободомыслие, рационализм, мистицизм и реформаторство. Она включает в себя несколько принципиально различных направлений - суннизм, шиизм и суфизм. Следствием этого является возникновение множества богословских течений и организаций, многообразие и неоднородность которых лишь способствовали активизации философских изысканий. Возникло множество идейных течений, расходящихся во взглядах на сущность Аллаха и его атрибуты, Божественную справедливость и предопределение, веру и покаяние, Божественную благодать и др. спорные вопросы, вносящие в теорию и философию ислама огромное разнообразие. Ашариты и каррамиты, муджассимиты и мутазилиты, джабариты и мурджииты философски обосновывали свою точку зрения по этим вопросам в разные конкретноисторические периоды. Их философия представляет собой некую совокупность персонифицированных выдающимися учеными и теологами концепций.

Философия ислама рассматривает религию и Бога отстраненно, в системе других явлений человеческого духа, с точки зрения критического разума. Она исследует сущность религии, существование, причины происхождения, необходимость и случайность, свободу воли, атрибуты Бога и другие вопросы, которые составляют философскую онтологию ислама. Гносеологические проблемы философии ислама состоят из выяснения его способности адекватно отражать мир, анализа божественных и человеческих средств и способов познания, роли в нем языка и т. п. Многие века изучение философии было нераздельно связано с освоением Корана и Сунны. Она по существу совпадает с богословием, теологией, поскольку создавалась одними и теми же авторами - философами-теологами. Даже тогда, когда некоторые суфийские философы отстаивали еретические с точки зрения ортодоксального ислама мысли. Поэтому познание в исламе движется по двум векторам - от реальной действительности к Корану и обратно, от него к миру. Наука, философия и исламская теология образуют единую неразрывную систему, поскольку объектами исламской теологии является Аллах и религия, причем она их рассматривает с участием самой религии. По статусу теологии как науки человеческому разуму в решении философских вопросов приходит на помощь божественное откровение, как вторая, по выражению аль-Газали, ступень познания, с помощью которого открывается недоступное разуму. 


\section{Философия ислама и разум}

Другая особенность исламской философии - ее соотношение с разумом. Многовековая проблема веры и разума, откровения и познания, сопровождающая историю религии и философии на всем ее протяжении, смыкается с проблемой соотношения рациональных, нерациональных и иррациональных путей и средств познания. На первый взгляд, в исламе однозначно философия сводится к разуму, и многие исследователи склонны соотносить философию с разумом и рациональным, тогда как внерациональное относят к сфере религии [10, с. 195]. Но реальная история мусульманской религии свидетельствует об ином. Тот же суфизм со своими экстазом, озарением, мистицизмом в рамках ислама проявляется с уже сложившейся системой элементов познавательной культуры, характерных, скажем, для неоплатонизма, китайской и индийской философских систем. Эпоха той же исламской религии аккумулировала, а затем и монополизировала и архаические, и современные ей научно-философские достижения человеческого познания, многие из которых позже подверглись упрощенной демаркации, в особенности в классический период развития и науки, и философии. Ныне они обретают утерянное, возвращают раздаренное другим сферам духа, в том числе монополизированное религией [6; 7]. Возможно, пришло время разбавить строгие классические определения философии новизной постмодернистских размышлений.

Таким образом, основной особенностью исламской философии является ее самоотождествление с разумом. Возможно, здесь кроются истоки жесткого противостояния ортодоксального ислама суфизму, в философии которого нерациональное и иррациональное играют значительную роль как в теории, так и в практике. Отметим, что философия суфизма является неотъемлемой частью исламской философии как целостной концепции.

\section{Исламская философия и арабо-мусульманская философия}

Со спецификой исламской философии связана и недавно разгоревшаяся в отечественной философии полемика о «логико-смысловой теории», выдвинутой лет двадцать назад академиком А.В. Смирновым. Эта теория утверждает, что арабомусульманская логика кардинально отличается от греческой (европейской, западной), характеризуя первую как выражение процессуального мировоззрения, а вторую субстанциального. По мнению академика, есть двоякая логическая формализация: первая осуществляется в системе допущений субстанциальной логики, где процедура дает только вероятностное суждение по аналогии; вторая - в системе допущений процессуальной логики, где она уже предстает как строгое аподиктическое доказательство с несомненным выводом. Как следствие, делается заключение об изначальной несводимой множественности разума [12].

В недавней дискуссии в журнале «Вопросы философии» $(2019$, № 2) с участием В.А. Лекторского, В.В. Васильева, И.Ф. Михайлова, В.И. Шалака и В.К. Солондаева философы в целом согласились: разум не только един, но и многообразен, что существуют разные типы рациональности. В ряде своих работ я уже писал о коренном отличии европейского разума от арабского, при этом я пользуюсь терминами «рационалистический», «рассудочный» и «иррационалистический», «познавательная культура» и т. п. Возможно, это отличие - последствие сложившейся в арабской философии традиции процессуальной онтологии, развитой арабскими перипатетиками, и тогда есть основания говорить о процессуальной логике или метафизике.

В то же время некоторые положения вызывают сомнение. Об этом пишет И. Михайлов (см. [11]) и основной оппонент А. Смирнова, главный научный 
сотрудник Центра арабских и исламских исследований Института востоковедения РАН Тауфик Ибрагим: «Как в европейском, так и в арабском силлогизме логическое следование имеет теоретико-множественную природу». Также уязвима идея «особых когнитивных интуиций, лежащих в основе арабского языка и логики». На мой взгляд, различие образа мышления в двух культурах - следствие разновекторного тысячелетнего развития, не генетического, а скорее культурного кода, сформировавшегося и в Европе, и на Востоке в своеобразных архетипах культуры. Дальнейшее развитие познавательной культуры и исламской философии требует преодоления амбиций арабской философии (которая пытается выступать от имени мусульманской философии в целом) и признания статуса суфизма как философии. Безусловно, противоречия между ортодоксально-исламской (суннитской) рационалистической философией и суфийской мистико-иррациональной объяснимы, по крайней мере, различными культурными кодами арабской нации и неарабских народов, исповедующих ислам, многие из которых из-за географической близости к буддизму и шаманизму имеют свои особенности мировосприятия.

В отличие от христианской и буддийской религий, в исламе намного чаще вносятся поправки и дополнения в эмпирическую, фактологическую базу для концептуального обоснования постулатов Корана, особенно после того, как в течение столетий богословы искажали священную книгу. Адекватно перевести Коран довольно сложно. Тот же Т. Ибрагим обращает внимание на неоднозначность многих утверждений Корана и хадисов. «Символы и метафоры отражают факт наличия у коранических откровений двух планов, или аспектов, - внешнего (буквального) и внутреннего, ориентированных соответственно на широкую публику и просвещенную элиту». Он отмечает, что в исламе приветствуется изучение и познание людьми природы и общества. «В многочисленных местах Коран призывает людей поразмыслить над царящей в мире гармонией и красотой... Словно рефреном, в Писании звучат выражения типа «размышляйте», «назидайтесь», «вникайте», «неужто они не разумеют», «для людей понимающих» и т. д.» [9, с. 172-173]. Так что в том же исламе и религиозным, и светским ученым еще многое предстоит открыть и осмыслить.

\section{Претензии исламской философии на то, что только ей доступно истинное познание}

Эта установка в исламе отличает его от других религий. Ислам претендует на роль единственного и абсолютного носителя истины в последней инстанции. Эта точка зрения, естественно, оспаривалась представителями иных религий, а также различными течениями внутри ислама. В последние годы активизировались исследования ислама. Ученые стремятся глубже осмыслить исламское вероучение с целью опровержения его отождествления с абсолютной истиной. Здесь снова уместна ссылка на статью академика РАН А.В. Смирнова [13], поскольку ему в последние годы удалось теоретически обосновать и даже популяризировать весомые аргументы о тщетности попыток любой религии узурпировать истину. Более того, он одним из первых вмешался в ситуацию вокруг ислама - аргументированно доказал, что тоталитаризм чужд исламу и невозможно объявить некий вариант исламского вероучения единственно истинным и обязательным для всех. По его мнению, ислам как религия и как культура просто-напросто не имеет механизмов навязывания единого мнения, и если кто-то сегодня пытается такие механизмы запустить, такой человек действует явно вразрез с фундаментальной логикой ислама. «Многовариантность встроена в саму систему ислама как живого, развивающегося 
организма» [14, с. 46]. Эта идея чрезвычайно актуальна особенно в условиях противостояния в мусульманских регионах России суфизма и салафизма.

Помимо исследования ислама и его философии необходимо выработать новый тип мышления как ведущего компонента всего комплекса религиозных усилий по совершению «революции», «великого джихада», который столетия является предметом острых политических и теоретических дискуссий мусульманской уммы. Отмечая, что разные исследователи по-разному толкуют понятие «джихад» $[4 ; 5 ; 15]$, автор данной статьи применяет его в значении духовного самосовершенствования, изменения состояния души, религиозного сознания. Однако в реализации интеллектуальнофилософского акта единения мусульман в соответствии с Кораном, если даже будут солидарны все идеологические и политические направления ислама, они вряд ли будут действовать в унисон и вложат в эту выработку новой мыслительной стратегии одинаковые смыслы. Предлагаемая нами смысловая версия исходит из анализа сложившихся в исламе и его философии познавательных традиций, на которых были основаны толкования Корана и всей сути ислама, и заключается в синтезе арабской рациональности и суфийской иррациональности. Мы считаем, что, взаимообогащение этих традиций, интеграция или синтез их достоинств - путь к выработке эффективного типа мышления, как для осмысления современной культуры и цивилизации, так и для единения различных направлений ислама [8].

При всей революционности «великого джихада» он должен сохранить преемственность традиций. Вот почему современный вектор эффективной мыслительной стратегии теоретического осмысления мусульманской религии должен быть исторически детерминирован. Как известно, издавна ислам и его философию питают истоки, по крайней мере, двух идейный течений - исламской духовности и мистицизма аль-Газали, с одной стороны, рационализм Ибн Сины - с другой. При этом эти истоки не столь отдаленные, хотя в них аккумулированы относительно противоположные интеллектуальные тенденции первых нескольких веков ислама. И во многом онтологические и гносеологические проблемы внутри ислама сохраняют свои традиционные противоречия. По нашему мнению, водораздел проходит между противоположными положениями суфизма и ортодоксального ислама, под которым мы в данной статье понимаем преимущественно суннизм. И коль скоро ислам претендует на интеллектуальное совершенство и на создание адекватной картины мироздания, то он должен стремиться к объединению достоинств различных направлений, не лишая их своих особенностей.

Вообще, на первый взгляд, кажется, что философское проявление мусульманства не соответствует масштабу и значимости исламской религии в истории человечества. И здесь есть над чем подумать: действительно ли правы мыслители, скептически оценивающие вклад ислама в философию? Ведь то же христианство породило в Новое время эталоны мысли европейской классической философии, тогда как мусульманская философия в своих известных достижениях общечеловеческой значимости гораздо скромнее, даже в период наивысшего расцвета в сердцевине арабской культуры, не говоря о ее периферийных частях. Возможно, все дело в малоизученности духовного ареала мусульманской культуры, в европоцентризме в устоявшейся гуманитарной методологии. Будем надеяться, дальнейшее развитие мировой исламской философии, ее национальных ответвлений позволит ответить на этот вопрос.

Свой посильный вклад в изучение ислама вносит научно-теоретический журнал «Исламоведение». Был проведен форум, приуроченный к его 10-летнему юбилею. Исламоведческий форум «Ислам и исламоведение в современной России» проводился с целями определения современного состояния исламоведения в России и мире в целом, 
привлечения научного интереса к проблемам исламоведения, а также поддержки профессиональных связей и научного взаимодействия между исследователями и исследовательскими группами России и ближнего зарубежья. Журнал пытается аккумулировать и стимулировать исламоведческие и общерелигиоведческие исследования на Северном Кавказе и в Дагестане. Работа непростая, ведь какой-либо значительной философской традиции и философской культуры в регионе мусульманского Кавказа не сложилось, разве что адаптированные к менталитету местных этносов учения отдельных суфийских сект. В мире и России в последние десятилетия наблюдается ренессанс религии (или псевдорелигии?). Необходим своеобразный анамнезис прерванного в нашей стране исторического развития общественного сознания, культурообразующими составляющими которого веками являлись христианство, ислам и буддизм. Одним этим, может, и не объяснишь дефицит исследований религии, но уже давно наука о религии застыла на эмпирическом уровне философы и политологи толкуют постулаты и аяты, не стесняясь выдавать за теорию пространные изложения и комментарии священных текстов того или другого вероисповедания.

Тем не менее, несмотря на все перипетии, ислам сумел полностью сохранить свою уникальность и целостность, наращивая и развивая усилиями многих народов и культур основной философско-религиозный потенциал в вопросах решения проблем мироздания, человека и Бога. В настоящее время сформировался универсальный философско-мировоззренческий теоретический понятийный аппарат.

\section{Исламская философия и национальная философия Дагестана}

Для философского сообщества представляет интерес вопрос о влиянии мусульманской философии на общественно-политическую мысль народов мусульманских регионов России. Насколько вообще корректен сам вопрос о национальной философии? Сомнения возникают уже на этапе осмысления статуса этого термина, поскольку философии, являющейся по своей сути предельно абстрактной и всеобщей теоретической конструкцией, высшей формой рациональной коммуникации, вроде бы чужды регионализация и национализация. Но, с другой стороны, все формы общественного сознания, в том числе самые высокотеоретизированные научные построения, как показывает история человеческого духа, несут в себе печать ментальных, психологических, климатических, соматических и т. п. особенностей субъектов творчества. Да и само формирование философии включает множество разнообразных эмпирических фрагментов, нанизанных на общемировоззренческую канву, вследствие чего трехтысячелетняя история древней науки предстает в известных исторических типах, формах и направлениях.

И если в таком единстве исторического и логического подойти к статусу понятия «национальная философия», то безусловно его категориальное право на бытие. Другое дело, насколько конкретные проявления национальной философии состоятельны с точки зрения философии науки, методологических притязаний самой философии. Но многое здесь познается в сравнении. Говоря об истоках и становлении национальной философии в том или ином регионе мира, невозможно отвлечься от генезиса древнейшей национальной философии - древнегреческой философии. Однако в реальности с таким ярким образцом несопоставима ни одна национальная философия даже позднейшего периода. Классические характеристики античной культуры позволяют сделать вывод: язычество на территории Северного Кавказа и Дагестана как культурно-религиозное явление не отличалось философской глубиной, целостностью и значимостью своего влияния. Никаких письменных памятников, имен или философски значимых идей языческой культуры не сохранилось. 
Тем не менее, как свидетельствует история Дагестана, язычество с большим трудом веками преодолевалось поочередно доминировавшими монотеистическими религиями - иудаизмом, христианством, а впоследствии и ныне - исламом. Очевидно, региональная культура Дагестана обогащена этими и рядом других исторически значимых цивилизаций и целостных мировоззрений. Хотя генетический код духовности наших этносов разложить по его интеллектуальным составляющим не представляется возможным никакими современными принципами, можно констатировать: становление национального самосознания, его выжимки в виде философской рефлексии над собственным духом, вековые обычаи, ритуалы и традиции обрели контуры исламской культуры с определенной метафизической глубиной.

Религия ислама, в т. ч. в его философском обличии, открыла дагестанцам доступ к духовным ценностям не только мусульманского региона, но и античной и в целом европейской культуры. Предпочтительное распространение в регионе получила мистическая ветвь ислама - суфизм. Это обусловлено, на наш взгляд, несколькими обстоятельствами, решающим из которых является следующее: суфийская разновидность мусульманства, ставшая впоследствии традиционной для региона, обладала наибольшим адаптационным ресурсом к природно-климатическим, этнопсихологическим и культурным условиями бытия местных этносов.

Так или иначе встает вполне правомерный вопрос о существовании национальной дагестанской философии и о ее содержательных проявлениях. Один из исследователей, Магомед Абдуллаевич Абдуллаев, посвятивший свое научное творчество осмыслению духовной культуры народов Дагестана с древнейших времен до наших дней, утверждает, что национальная философия в Дагестане существует. Его методология основана на положении о расширительном толковании предмета истории философии, включая в него «не только философские, логические, эстетические, этические, но и социально-политические проблемы» [1, с. 12]. Автор аргументирует свою позицию тем, что философия служит «методологической и общетеоретической основой... всей духовной культуры», а поскольку «в духовной жизни горцев господствовала религиозная идеология», постольку это «препятствовало развитию философского мышления и философской мысли» из-за отсутствия письменности у ряда народов, «философских учреждений и периодики», а «народные массы выражали свои мечты и стремления, свое отношение к социальной действительности и к мирозданию в фольклоре, а передовые люди преимущественно в поэзии» [1, с. 13-14].

Однако заметим, что философия является методологией всей духовной культуры в принципе. Другое дело, что такая методология появляется в основном в трудах наших современников, в первую очередь самого профессора М. Абдуллаева. Отсутствие собственно философских разработок, хотя философские идеи и содержались в фольклоре, поэзии и религиозных взглядах, не позволяет, разумеется, говорить об истории философии (даже в ее расширительном понимании) региона. И даже при том, что на Северном Кавказе культивировался суфизм - наиболее насыщенная философским содержанием ветвь ислама, в регионе вплоть до XX века не появились зачатки профессиональной философии.

\section{Выводы}

У конкретной религии и ее философии взаимоотношения несколько проще, чем у религии и философии как исторических типов мировоззрений. Как свидетельствует философия ислама, исламская философия и религия ислама не испытали противоречивой связи, особой состязательности или интеллектуального 
противоборства. Им присущи генетические причинно-следственные взаимоотношения. В отличие от философий буддизма и христианства, исламская философия возникла значительно позже своей религиозной основы, строго следуя в своем развитии Корану. Познание в исламе имеет два вектора - от реальной действительности к Корану и от него к миру, т. е. наука, философия и исламская теология образуют единую неразрывную систему.

Несмотря на доминирующую интенцию исламской философии на eе самоотождествление с разумом, приводящую к жесткому противостоянию ортодоксального ислама и суфизма, для сохранения концептуальной целостности исламской философии важна неотъемлемость от нее философии суфизма, который предельно расширяет мыслительный диапазон человеческого познания за счет иррационального.

Следующую особенность исламской философии наше исследование выводит из полемики вокруг «логико-смысловой теории» А. Смирнова. Одним из оснований для такой полемики, на наш взгляд, служит объективное противоречие между ортодоксально-исламской (суннитской) рассудочно-разумной мыслью и суфийской мистико-иррациональной мыслительной стратегией. Исламская философия как глобальная теоретическая система творилась арабской нацией, с одной стороны, и обладавшими отличным от нее культурным кодом обширного ареала народов мусульманского Востока, с другой стороны.

В историко-логической связи с предшествующими выводами еще одна специфика исламской философии - ее многовариантность, отказ от навязывания верующим единого мнения, от претензии на абсолютную истинность, что является основой толерантности ислама.

\section{Литература}

1. Абдуллаев М.А. Из истории философской и общественно-политической мысли Дагестана (с древнейших времен до присоединения Дагестана к России). Махачкала: Юпитер, 1993.

2. Аль-Кинди. О первой философии // Антология мировой философии: в 4 т. М.: Мысль, 1969. Т. 1, ч. 2.

3. Аль-Фараби. Социально-этические трактаты. - Алма-Ата: Наука, 1973.

4. Бабаев Ф.М. Джихад как феномен в исламе // Исламоведение. - 2009. - № 1. - C. 40-49.

5. Баширов Л.А. Ислам о войне и мире// Государство, церковь, религия в России и за рубежом. - 2011. - № 2. - С. 186-202.

6. Билалов М.И. Религиозное познание в культуре постижения истины // Исламоведение. - 2017. - Т. 8, № 2 (32). - С. 19-27.

7. Билалов М.И Постижимость истины: уловимость, объяснимость, выразимость. - Махачкала: Дагестанское книжное издательство, 2017. - 376 с.

8. Билалов М.И. Смена типов мышления в процессе «великого джихада» в исламе // Ислам в современном мире. - 2017. - № 13 (1). - С. 167-182.

9. Ибрагим T. На пути к коранической толерантности. - Н. Новгород: Издательский дом «Медина», 2007. - С. 173-172.

10. Келигов М.Ю. Философская и религиозная составляющие человеческого духа. - М.: Академический проспект, 2019. - 195 с. (Философские технологии).

11. Михайлов И.Ф. Могут ли люди мыслить по-разному? // Вопросы философии. - 2019. - № 2. - С. 27-34.

12. Смирнов А.В. Процессуальная логика и ее обоснование // Вопросы философии. - 2019. - № 2. - С. 5-17.

13. Смирнов А.B. Открытое всеединство нашей философии // Вопросы философии. - 2017. - № 7. 
14. Смирнов А.В. Классический ислам и современный Дагестан: как можно сегодня прочитывать исламское наследие // Проблемы российского самосознания: историческая память народа; материалы 12-й Всероссийской конференции. Москва-Махачкала, апрель 2015 г. - М.; Махачкала: Дельта-пресс, 2015. - С. 4353.

15. Хайретдинов М.3. Джихад сквозь призму современной эпохи. - М.: Медина, 2014.

\section{References}

1. Abdullaev M. A. From the History of Philosophical and Socio-Political Thought of Dagestan (from Ancient Times till Joining Russia). MRIP "Jupiter", Makhachkala, 1993. (in Russian)

2. Al-Kindi. On the Earliest Philosophy. The Anthology of World Philosophy: in 4 vol. Moscow. Thought, 1969.Vol. 1. Part 2. (in Russian)

3. Al-Farabi. Social and Ethical Treatises. Alma-Ata. Science, 1973. (in Russian)

4. Babayev F.M. Jihad as a Phenomenon in Islam. Islamovedenie, № 1, 2009. pp. 40-49. (in Russian)

5. Bashirov L.A. Islam on War and Peace. State, Church, Religion in Russia and Abroad, no. 2, 2011. pp. 186-202. (in Russian)

6. Bilalov M.I. Religious Knowledge in the Culture of Truth Comprehension. Islamovedenie. 2017. Vol. 8, № 2 (32). pp. 19-27. (in Russian)

7. Bilalov M. The Comprehension of Truth: Subtlety, Explicability. Expressiveness. Makhachkala: GAU RD "Dagestan book publishing house", 2017. 376 pp. (in Russian)

8. Bilalov M.I. The Change of Types of Thinking in the Process of "Great Jihad" in Islam. Islam in the modern world. 2017, № 13 (1), pp. 167-182. (in Russian)

9. Ibrahim T. Towards Quranic Tolerance. N.Novgorod: Publishing house "Medina", 2007. pp. 173, 172. (in Russian)

10. Keligov M.Yu. Philosophical and Religious Components of the Human Spirit. Moscow. Academic Avenue, 2019. 195 pp. (Philosophical technologies). (in Russian)

11. Mikhailov I.F. Can People Think Differently? Issues of Philosophy. 2019, № 2. pp. 27-34. (in Russian)

12. Smirnov A.V. Procedural Logics and Its Justification. Issues of Philosophy. 2019, № 2. pp. 5-17. (in Russian)

13. Smirnov A.V. Open Unitotality of Our Philosophy. Issues of Philosophy. 2017, № 7. (in Russian)

14. Smirnov A.V. Classical Islam and Contemporary Dagestan: How Can One Interprete Islamic Heritage Today. The Issues of Russian Identity: the Historical Memory of the People. Prceedings of the 12 $2^{\text {th }}$ All-Russian conference. Moscow-Makhachkala, April 2015. - Moscow; Makhachkala: Delta press, 2015. pp. 43-53. (in Russian)

15. Khayretdinov M.Z. Jihad through the Prism of the Modern Age. Moscow. Medina, 2014. (in Russian) 